\title{
FGF2-induced effects on transcriptome associated with regeneration competence in adult human fibroblasts
}

\author{
Olga Kashpur ${ }^{1}$, David LaPointe², Sakthikumar Ambady ${ }^{3}$, Elizabeth F Ryder ${ }^{1}$ and Tanja Dominko ${ }^{*}$
}

\begin{abstract}
Background: Adult human fibroblasts grown in low oxygen and with FGF2 supplementation have the capacity to tip the healing outcome of skeletal muscle injury - by favoring regeneration response in vivo over scar formation. Here, we compare the transcriptomes of control adult human dermal fibroblasts and induced regenerationcompetent (iRC) fibroblasts to identify transcriptional changes that may be related to their regeneration competence.

Results: We identified a unique gene-expression profile that characterizes FGF2-induced iRC fibroblast phenotype. Significantly differentially expressed genes due to FGF2 treatment were identified and analyzed to determine overrepresented Gene Ontology terms. Genes belonging to extracellular matrix components, adhesion molecules, matrix remodelling, cytoskeleton, and cytokines were determined to be affected by FGF2 treatment.

Conclusions: Transcriptome analysis comparing control adult human fibroblasts with FGF2-treated fibroblasts identified functional groups of genes that reflect transcriptional changes potentially contributing to their regeneration competence. This comparative transcriptome analysis should contribute new insights into genes that characterize cells with greater regenerative potential.
\end{abstract}

Keywords: Transcriptome, Human fibroblasts, Fibroblast growth factor (FGF2), Wound healing, Regeneration

\section{Background}

During development, distinct cell phenotype differentiation is guided by finely tuned and orchestrated changes in transcriptional activity of specific groups of genes that become gradually activated (lineage-specific), gradually repressed (stem cell and progenitor cell genes), or whose activity does not change substantially (housekeeping genes). Ultimately, analyzing the transcriptome of a cell type offers an opportunity to broadly identify transcripts that define it. In addition to these either developmentally regulated or artificially induced phenotype changes that are accompanied by distinct transcriptional changes, a transcriptome of any given cell type can vary substantially depending on cell cycle [1-3], passage number, and environmental factors such as oxygen concentration [4], temperature, and presence of serum [5].

\footnotetext{
* Correspondence: tdominko@wpi.edu

'Department of Biology and Biotechnology, Worcester Polytechnic Institute, 100 Institute Road, Worcester, MA 01609, USA

Full list of author information is available at the end of the article
}

Another important factor that causes transcriptional changes and is crucial for maintaining a cell phenotype is growth substrate. For example, maintenance of undifferentiated state of embryonic stem cells is dependent on favorable substrate, composed of laminin [6-9], vitronectin [9-12], fibronectin [9], and collagen IV [8]. In addition to chemical composition, physical properties of substrate also determine cell fate. Roughness and stiffness of the surfaces have also been shown to affect developmental plasticity of cells. Smooth and rigid glass surface supports undifferentiated phenotype, while rough and soft substrates promote differentiation $[13,14]$.

Lastly, presence of various growth factors in culture media can have a significant effect on a cell transcriptional activity and consequently its phenotype. FGF2 is a mesenchyme-derived growth factor that displays mitogenic, migratory, and morphogenic functions and is also known to play role in angiogenesis, organ development, organ regeneration, and wound healing [15]. Contrary to its predominantly mitogenic effects on

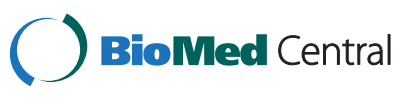


differentiated cell types, FGF2 is absolutely required for maintenance of expression of stemness-related genes. With respect to wound healing, FGF2 has been studied as a potential therapeutic anti-scarring agent [15-17].

We have previously investigated the effects of the aforementioned important cell culture conditions, FGF2 and culture surface, on adult human fibroblasts. We have observed that adult human fibroblasts demonstrated FGF2- and surface-mediated induction of some endogenous stem cell genes and a capacity to acquire a more developmentally plastic phenotype. This low level of activation of stem cell genes was not sufficient for induction of a phenotypic conversion into a pluripotent cell phenotype [18]. However, when transplanted into skeletal muscle injury, adult human fibroblasts grown in low oxygen and with supplementation of FGF2 had the capacity to tip the healing outcome of skeletal muscle injury - by favoring regeneration response in vivo over scar formation [19]. The wound repair process consists of several phases, including immediate response to injury, inflammatory response, cell proliferation and migration, ECM contraction, and ECM remodeling. The roles of dermal fibroblasts in wound healing have been described [20] and in mammals fibroblasts facilitate collagen deposition and formation of a scar. The cascade of molecular events leading to scar formation involves increased proliferation and migration of fibroblasts in response to growth factors [21], production and organization of specific ECM components [22,23], and acquisition of an actin-dependent contractile phenotype [24]. The wound repair process is complete by formation of a scar (disorganized extracellular matrix, mainly collagen) [20].

In this study, we compared transcriptomes of control fibroblasts and regeneration- competent fibroblasts to determine whether transcriptional profile that characterizes regeneration-competent cells reflects disregulation of genes involved in the default wound healing pathway leading to scar formation - turning the cells into a more pro-regenerative phenotype.

\section{Results}

\section{The effect of cell growth surface and FGF2 on fibroblast transcriptome}

To obtain a sense of the effects of surface and FGF2 treatment on global transcription, two independent samples (in three technical replicates each) of human dermal fibroblasts grown on glass, glass with FGF2, plastic, and plastic with FGF2 were hybridized to the Human Whole Genome OneArray microarray, which contains 29,187 human oligonucleotide probes. Backgroundcorrected intensity data was normalized and filtered, which identified 11,124 probes of detectable level of intensity (Additional file 1). The gene expression dataset is of excellent quality as indicated by Pearson's correlation coefficients for biological replicates: 0.987 for glass, 0.973 for glass with FGF2, 0.960 for plastic, and 0.971 for plastic with FGF2 (Additional file 2). To investigate cell culture effects, we examined significantly differentially expressed gene probes using moderated $\mathrm{t}$-statistic and based on the false discovery rate (FDR) cutoff value of 0.05. Comparison of transcriptomes between cells grown on glass and plastic in the absence of FGF2 did not identify any differentially expressed genes. However, FGF2-induced changes in gene expression depended on surface.

FGF2 had a more prominent effect on cells when grown on plastic than on glass, as determined by the overall increased number of differentially expressed gene probes (3,349 on plastic versus 2,185 on glass) (Figure 1A). In response to FGF2 treatment, 2,012 differentially expressed gene probes $(1,767$ genes) were identified that were disregulated on both surfaces: 1,209 common gene probes were upregulated (1,071 genes) (Figure 1B) and 803 common gene probes downregulated (696 genes) (Figure 1C). In addition to these common genes, FGF2 treatment disregulated 173 unique gene probes (168 genes: 139 upregulated and 29 downregulated) on glass and 1,337 unique gene probes (1,282 genes: 753 upregulated and 529 downregulated) on plastic (Figure 1). The complete list of differentially expressed gene probes on glass and on plastic can be found in Additional file 3 and Additional file 4, respectively. The top 50 significantly differentially expressed genes are represented in the heat maps (Figure 2A and B, respectively). All further analyses were performed on genes whose expression was disregulated in cells grown in the presence of FGF2 on plastic.

\section{Gene ontology analysis}

Differentially expressed genes were analyzed for functional enrichment. To determine the functions of the genes affected by FGF2 treatment and consequently identify the cellular processes that are affected by these transcriptional changes, we performed Gene Ontology (GO) analysis. First, all significantly differentially expressed genes were analyzed to determine broad GO term overrepresentation using GO slim analysis. GO slim analysis identified broad terms describing biological processes (Figure 3A), molecular functions (Figure 3B), as well as cellular components to which they belong (Figure 3C). Additional file 5 includes the number of gene probes representing each GO slim term. A total of 664 overrepresented GO terms $(\mathrm{p}<0.05)$ associated with biological processes were identified. These included genes involved in regulation of cell cycle, cardiovascular system development, extracellular matrix organization, cell proliferation, cell adhesion, regulation of angiogenesis, cell migration, and wound healing. Seventy seven overrepresented GO terms $(\mathrm{p}<0.05)$ were associated with molecular function. The 


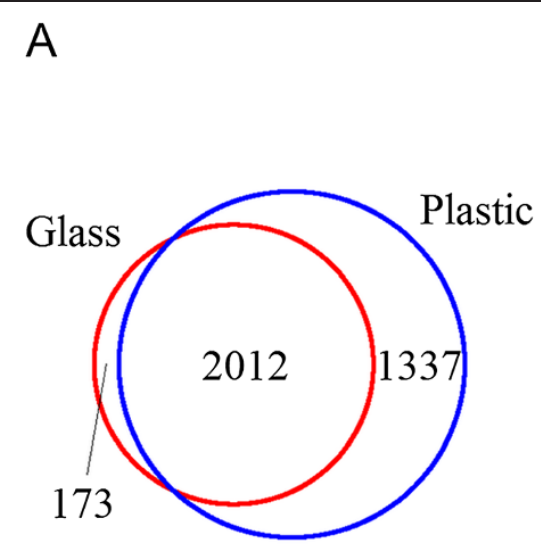

B
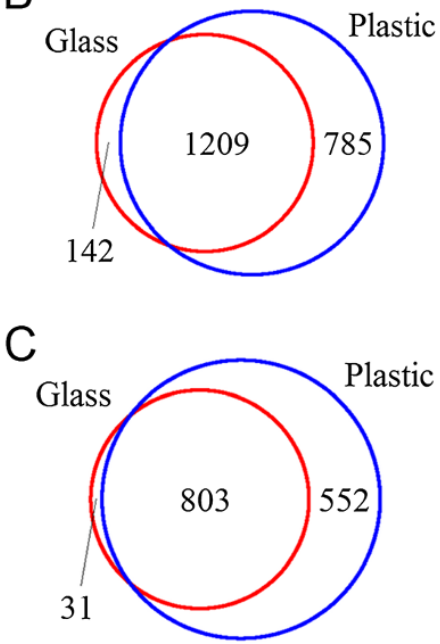

Figure 1 FGF2 changes gene expression in human fibroblasts. A. Venn diagram showing the overlap between differentially expressed gene probes on plastic and glass. B. Venn diagram depicting the overlap between upregulated gene probes on plastic and glass. C. Venn diagram depicting the overlap between downregulated gene probes on plastic and glass.

genes belonged to extracellular matrix structural constituents, genes regulating collagen, heparin, integrin binding, and genes regulating cytokine activity. Sixty five overrepresented GO terms $(\mathrm{p}<0.05)$ were associated with cellular components and belonged primarily to extracellular components (Additional file 6).

\section{Expression of genes associated with wound healing}

As FGF2-treated human dermal fibroblasts were previously shown to participate in wound healing of volumetric skeletal muscle by contributing directly to the pool of satellite PAX7 positive cells and by stimulating regeneration of endogenous skeletal muscle tissue [19], we focused further analysis of differentially expressed genes to those that play a role in wound healing and could be uniquely identifying regeneration-competent fibroblasts.

Overall, select genes belonging to extracellular matrix and its remodeling, inflammation, cytoskeleton and migration, and growth factor signaling were found to be affected by FGF2.

\section{Extracellular matrix, matrix remodeling enzymes, and adhesion molecules}

FGF2 treatment led to downregulation of most collagens (COL11A1, COL4A2, COL8A1, COL5A1, COL1A1, COL12A1, COL15A1) and fibronectin (FN1) and to upregulation of several laminins (LAMB1, LAMB3, LAMA3). FGF2 increased expression of select metallopeptidases (stromelysines MMP3, MMP10, and MMP11; MMP1; ADAMTS8), and metallopeptidase inhibitor TIMP4. Among downregulated genes were TIMP3, and several other ADAMTS proteinases (ADAMTS5 and
ADAMTS1). Different members of integrin family responded by significant upregulation (ITGA2, ITGA10, ITGB3) or downregulation (ITGA11, ITGB2). Significantly disregulated genes identified by the microarray are presented in Table 1. Expression levels of select target genes identified by the microarray (Figure 4A) were examined by qRT-PCR (Figure 4B).

\section{Cytoskeleton}

Another group of genes found to be regulated by FGF2 treatment were components of the cytoskeleton that are also involved in wound healing (Table 2). The most significant effect was observed on ACTC1 and ACTG2. Expression levels of ACTC1 and ACTG2 identified by the microarray (Figure 5A) were examined by qRT-PCR (Figure 5B).

\section{Cytokines, their receptors, and downstream signaling molecules}

Cytokines that were identified to be differentially expressed are listed in Table 3. FGF2-induced transcriptional increase was observed in genes associated with inflammation (CXCL1, CXCL5, PTGS2), and growth factor signaling (EGFR, HGF, MAPK1). Expression of pro-inflammatory cytokines interleukin-1B (IL1B) and IL6 decreased upon FGF2 treatment. Signal transducer and activator of transcription 3 (STAT3), which is a known downstream target of IL6 signaling, was downregulated as well as was another downstream IL6/STAT3 gene, CC chemokine ligand CCL2. Expression levels of all these targets identified by the microarray (Figure 5A) were confirmed by qRT-PCR (Figure 5B). FGF2 effect on expression of TGFB pathway genes included increase 

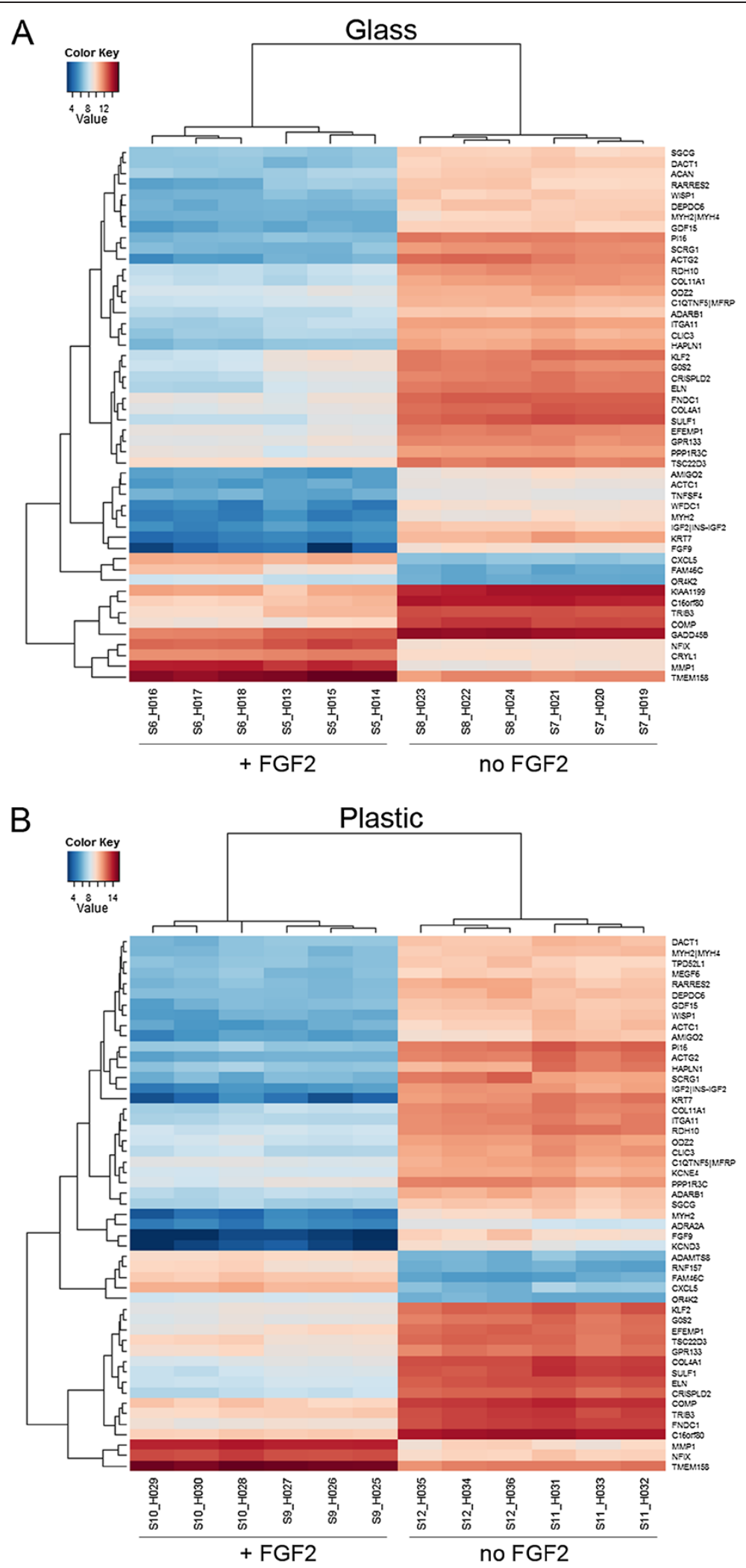

Figure 2 Top 50 differentially expressed genes due to FGF2 treatment. A. Heat map showing level of gene expression on glass. B. Heat map showing level of gene expression on plastic. 


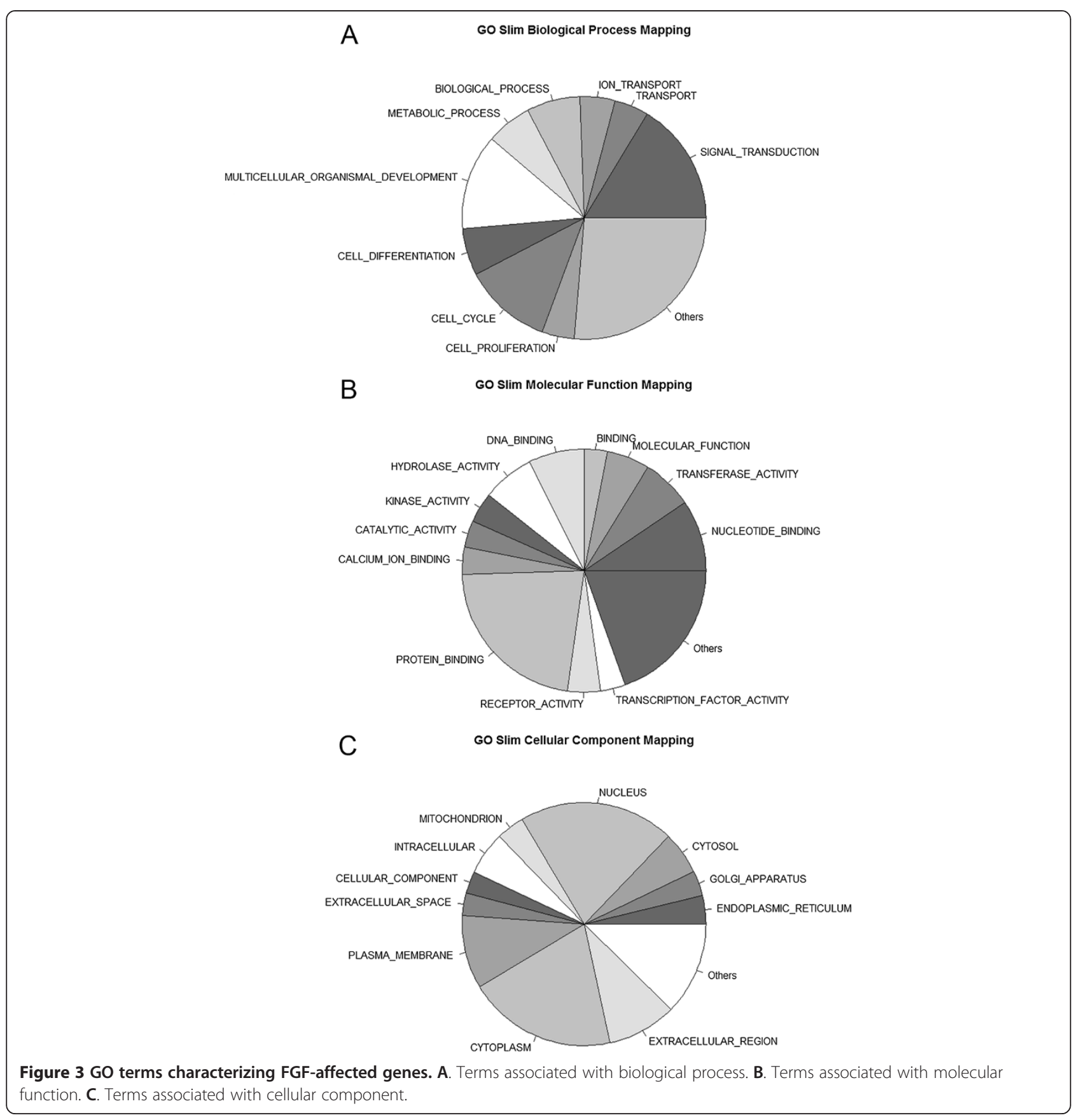

in TGFBR3 expression, decrease in TGFBR1, and decrease in TGFBI (Table 3). TGFB1 and TGFB3 were not significantly differentially expressed due to FGF2 treatment. qRT-PCR results for TGFB1 and TGFBR1 are presented in Figure 5B.

\section{Discussion}

The comparative transcriptome analysis described here demonstrates a unique molecular signature for induced regeneration-competent (iRC) fibroblasts compared with control fibroblasts. Consistent with the notion that these two cell types are distinctly different, we have used both cell types in in vivo regeneration experiments and demonstrated that the induced regeneration-competent fibroblasts participate in regenerative response of skeletal muscle (concomitant with decreased scar formation), contribute to the pool of newly established satellite cells (PAX7 ${ }^{+}$cells) in a mouse injury model, as well as form mature myotubes [19].

Identification of significantly differentially expressed genes and subsequent Gene Ontology analysis determined that a large number of genes important for the outcome 
Table 1 ECM, adhesion, and matrix remodeling genes affected by FGF2 treatment

\begin{tabular}{|c|c|c|c|c|}
\hline Symbol & Name & $\begin{array}{l}\log 2 \\
\text { fold change }\end{array}$ & Fold change & $\begin{array}{l}\text { Adjusted } \\
\text { p-value }\end{array}$ \\
\hline \multicolumn{5}{|l|}{ ECM } \\
\hline \multicolumn{5}{|l|}{ Collagens } \\
\hline COL21A1 & Collagen, type XXI, alpha 1 & 2.99 & 7.97 & 4.40E-06 \\
\hline COL14A1 & Collagen, type XIV, alpha 1 & 2.25 & 4.74 & $3.58 \mathrm{E}-05$ \\
\hline COL13A1 & Collagen, type XIII, alpha 1 & 1.62 & 3.07 & 0.003150228 \\
\hline COL18A1 & Collagen, type XVIII, alpha 1 & 1.40 & 2.64 & 0.026150843 \\
\hline COL6A3 & Collagen, type VI, alpha 3 & 1.02 & 2.02 & 0.026527481 \\
\hline COL10A1 & Collagen, type X, alpha 1 & 0.61 & 1.52 & 0.033185205 \\
\hline COL27A1 & Collagen, type XXVII, alpha 1 & -0.59 & -1.50 & 0.000481652 \\
\hline COL16A1 & Collagen, type XVI, alpha 1 & -0.86 & -1.82 & 0.000501675 \\
\hline COL1A2 & Collagen, type I, alpha 2 & -0.92 & -1.90 & 0.001062514 \\
\hline COL12A1 & Collagen, type XII, alpha 1 & -1.16 & -2.23 & 0.001285122 \\
\hline COL5A1 & Collagen, type $\mathrm{V}$, alpha 1 & -1.17 & -2.25 & 0.000370081 \\
\hline COL1A1 & Collagen, type I, alpha 1 & -1.26 & -2.40 & $2.50 \mathrm{E}-05$ \\
\hline COL15A1 & Collagen, type XV, alpha 1 & -1.40 & -2.64 & $6.04 \mathrm{E}-06$ \\
\hline COL8A1 & Collagen, type VIII, alpha 1 & -1.92 & -3.77 & $5.23 \mathrm{E}-08$ \\
\hline COL5A2 & Collagen, type V, alpha 2 & -1.99 & -3.96 & 0.000570978 \\
\hline COL5A3 & Collagen, type $V$, alpha 3 & -2.24 & -4.72 & 8.97E-06 \\
\hline COL4A4 & Collagen, type IV, alpha 4 & -2.34 & -5.07 & 0.001283892 \\
\hline COL4A2 & Collagen, type IV, alpha 2 & -2.40 & -5.28 & $3.02 \mathrm{E}-14$ \\
\hline COL11A1 & Collagen, type XI, alpha 1 & -4.27 & -19.37 & $4.50 \mathrm{E}-12$ \\
\hline COL4A1 & Collagen, type IV, alpha 1 & -4.61 & -24.43 & $3.58 \mathrm{E}-05$ \\
\hline \multicolumn{5}{|l|}{ Laminins } \\
\hline LAMA5 & Laminin, alpha 5 & 1.74 & 3.35 & $5.24 \mathrm{E}-06$ \\
\hline LAMB1 & Laminin, beta 1 & 0.68 & 1.60 & 0.026626565 \\
\hline LAMA4 & Laminin, alpha 4 & 0.66 & 1.58 & 0.030288975 \\
\hline LAMA3 & Laminin, alpha 3 & 0.62 & 1.54 & 0.033413419 \\
\hline LAMC2 & Laminin, gamma 2 & -0.78 & -1.72 & 0.001416011 \\
\hline LAMA2 & Laminin, alpha 2 & -0.81 & -1.76 & 0.048073235 \\
\hline LAMB2 & Laminin, beta 2 (laminin S) & -0.88 & -1.84 & 0.016068977 \\
\hline LAMC1 & Laminin, gamma 1 (formerly LAMB2) & -1.34 & -2.53 & $8.56 \mathrm{E}-05$ \\
\hline \multicolumn{5}{|c|}{ Fibronectins } \\
\hline FNDC4 & Fibronectin type III domain containing 4 & 1.27 & 2.41 & 0.000256057 \\
\hline FNDC3A & Fibronectin type III domain containing $3 \mathrm{~A}$ & 0.81 & 1.75 & 0.036705362 \\
\hline FNDC3B & Fibronectin type III domain containing 3B & -1.12 & -2.17 & 0.001723239 \\
\hline FN1 & Fibronectin 1 & -1.14 & -2.20 & 0.00019286 \\
\hline FNDC1 & Fibronectin type III domain containing 1 & -4.06 & -16.64 & $2.29 \mathrm{E}-12$ \\
\hline \multicolumn{5}{|c|}{ Adhesion molecules } \\
\hline \multicolumn{5}{|l|}{ Integrins } \\
\hline ITGA2 & Integrin, alpha 2 (CD49B, alpha 2 subunit of VLA-2 receptor) & 3.69 & 12.92 & 4.74E-06 \\
\hline ITGA10 & Integrin, alpha 10 & 2.62 & 6.14 & $3.90 \mathrm{E}-07$ \\
\hline ITGB3 & Integrin, beta 3 (platelet glycoprotein IIla, antigen CD61) & 2.37 & 5.16 & $8.55 \mathrm{E}-05$ \\
\hline ITGB1 & $\begin{array}{l}\text { Integrin, beta } 1 \text { (fibronectin receptor, beta polypeptide, antigen CD29 includes MDF2, } \\
\text { MSK12) }\end{array}$ & -1.66 & -3.15 & $6.42 \mathrm{E}-06$ \\
\hline
\end{tabular}


Table 1 ECM, adhesion, and matrix remodeling genes affected by FGF2 treatment (Continued)

\begin{tabular}{|c|c|c|c|c|}
\hline ITGBL1 & Integrin, beta-like 1 (with EGF-like repeat domains) & -2.31 & -4.97 & $6.78 \mathrm{E}-08$ \\
\hline ITGB2 & Integrin, beta 2 (complement component 3 receptor 3 and 4 subunit) & -3.34 & -10.15 & 0.000457236 \\
\hline \multicolumn{5}{|l|}{ Cadherins } \\
\hline CDHR3 & Cadherin-related family member 3 & 1.22 & 2.33 & 0.008261441 \\
\hline PCDHGC3 & Protocadherin gamma subfamily C, 3 & 1.21 & 2.32 & 0.007298787 \\
\hline PCDH9 & Protocadherin 9 & 1.19 & 2.29 & 0.001804197 \\
\hline PCDH10 & Protocadherin 10 & 1.08 & 2.11 & 0.00089387 \\
\hline $\mathrm{CDH} 11$ & Cadherin 11 , type 2 , OB-cadherin (osteoblast) & -0.72 & -1.64 & 0.025796984 \\
\hline PCDHB2 & Protocadherin beta 2 & -0.76 & -1.69 & 0.010987526 \\
\hline $\mathrm{CDH} 2$ & Cadherin 2, type 1, N-cadherin (neuronal) & -2.05 & -4.14 & 1.11E-05 \\
\hline $\mathrm{PCDH7}$ & Protocadherin 7 & -2.36 & -5.12 & 0.002357001 \\
\hline \multicolumn{5}{|c|}{ Matrix remodeling } \\
\hline MMP1 & Matrix metallopeptidase 1 (interstitial collagenase) & 4.37 & 20.61 & $8.28 \mathrm{E}-12$ \\
\hline ADAMTS8 & ADAM metallopeptidase with thrombospondin type 1 motif, 8 & 3.31 & 9.94 & 1.65E-10 \\
\hline MMP27 & Matrix metallopeptidase 27 & 1.90 & 3.72 & 4.70E-06 \\
\hline MMP10 & Matrix metallopeptidase 10 (stromelysin 2) & 1.81 & 3.52 & 0.000118221 \\
\hline MMP3 & Matrix metallopeptidase 3 (stromelysin 1, progelatinase) & 1.81 & 3.51 & 7.05E-06 \\
\hline TIMP4 & TIMP metallopeptidase inhibitor 4 & 1.53 & 2.88 & 0.000259942 \\
\hline ADAM15 & ADAM metallopeptidase domain 15 & 1.04 & 2.06 & 0.000703266 \\
\hline ADAMTSL4 & ADAMTS-like 4 & 0.83 & 1.77 & 0.040463485 \\
\hline MMP11 & Matrix metallopeptidase 11 (stromelysin 3) & 0.82 & 1.76 & 0.009142377 \\
\hline ADAMTSL1 & ADAMTS-like 1 & 0.68 & 1.60 & 0.024404628 \\
\hline THBS2 & Thrombospondin 2 & -0.60 & -1.52 & 0.033809806 \\
\hline ADAM19 & ADAM metallopeptidase domain 19 & -0.82 & -1.77 & 0.016522395 \\
\hline TIMP3 & TIMP metallopeptidase inhibitor 3 & -1.48 & -2.78 & $8.49 \mathrm{E}-06$ \\
\hline ADAM12 & ADAM metallopeptidase domain 12 & -2.72 & -2.23 & $1.30 \mathrm{E}-08$ \\
\hline ADAMTS1 & ADAM metallopeptidase with thrombospondin type 1 motif, 1 & -3.06 & -8.32 & $4.12 \mathrm{E}-08$ \\
\hline ADAMTS5 & ADAM metallopeptidase with thrombospondin type 1 motif, 5 & -3.99 & -15.84 & 0.000108412 \\
\hline
\end{tabular}

of wound healing such as extracellular matrix genes, adhesion molecules, matrix remodeling genes, and genes involved in inflammation were regulated by FGF2 (Figure 3).

During dermal wound healing, fibroblasts are responsible for ECM production [17] and, here, we show that FGF2 treatment affects a number of genes involved in production and remodeling of ECM. FGF2 caused downregulation of a number of collagens such as collagen IV, collagen XI, collagen V, and collagen I, as well as caused upregulation of collagen XXI and collagen XIV (Table 1). qRT-PCR analysis confirmed downregulation of COL1A1, COL4A1, COL4A2, COL4A4, COL8A1, and COL11A1 (Figure 4B). FGF2 was previously shown to downregulate expression of interstitial collagen I and III [16]. Collagen I is a major component of ECM in skin, and during wound healing is the main scar forming collagen. Collagen IV is a major constituent of basement membrane (other components include laminin, nidogen, and heparan sulfate proteoglycan perlecan) and is a predominant type of collagen found in skeletal muscle. Other ECM genes affected by FGF2 treatment included laminins and fibronectins (Table 1). Most profoundly affected by FGF2 treatment were laminin gamma 1 (LAMC1) and laminin alpha 5 (LAMA5). qRT-PCR confirmed increased expression levels of these two laminins (Figure 4B). Fibronectin 1 was downregulated by FGF2 treatment (Figure 4B). FGF2 treatment of human fibroblasts modulates production of the ECM. The ECM composition of the FGF2-treated fibroblasts favors the pro-regenerative outcome in the wound site directly by affecting the balance between scar formation and tissue regeneration and potentially thorough changes in cell attachment to ECM, cell migration, and cell proliferation.

Cell attachment to the ECM is regulated through integrins, heterodimers that recognize specific substrates. Adhesion and migration on collagen substrate is performed through $\alpha 1 \beta 1$ and $\alpha 2 \beta 1$ and formation of 


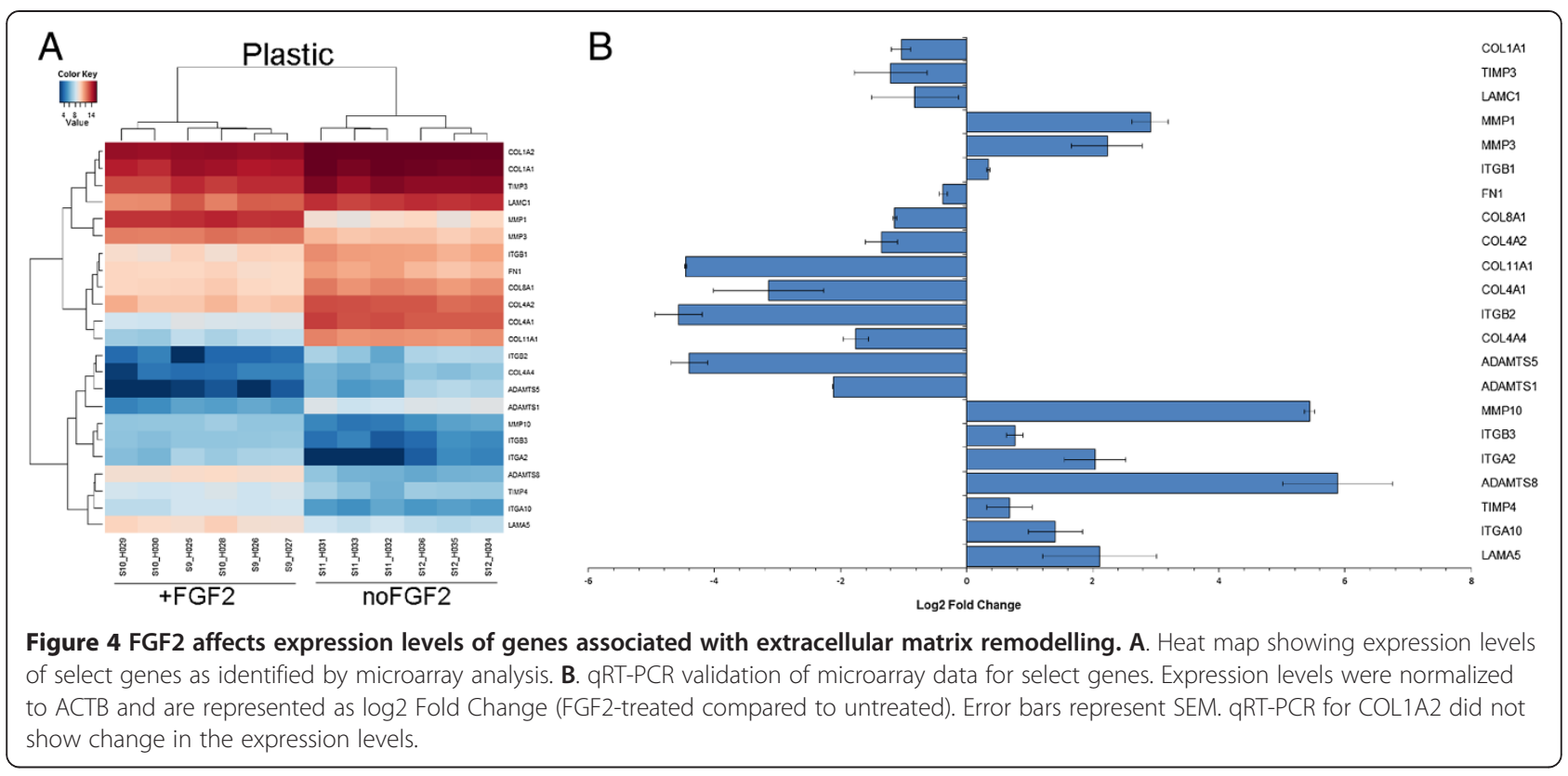

collagen type I and type III network is dependent on fibronectin and $\alpha 2 \beta 1$ [25-27]. We show FGF2-induced upregulation of $\beta 1$ and $\alpha 2$ (Figure 4B). Integrins $\alpha 5 \beta 1$, $\alpha \mathrm{V} \beta 3$, and $\alpha 4 \beta 1$ pairs are utilized to bind fibronectin matrix $[28,29], \alpha \mathrm{V} \beta 5$ is used to adhere to vitronectin, and $\alpha 6 \beta 1, \alpha 2 \beta 1, \alpha 3 \beta 1$ to adhere to laminin and entactin $[10,12,30]$. FGF2 treatment downregulated ITGB2 and upregulated ITGB3 and ITGA10 (Figure 4B). Integrins connect ECM to actin cytoskeleton via focal adhesions rich in talin, which is recruited to F-actin, and binds integrin pairs, which in turn leads to transmission of F-actin movements to ECM [29]. Change in the composition of integrins, as well as in the components of focal adhesions leads to change in migration, as well as preferential binding to specific substrate, production of which is regulated by FGF2 treatment, and may benefit a pro-regenerative response.
During wound healing, fibroblasts acquire a highly migratory phenotype. The process is driven by actin polymerization and resulting microfilaments of the cell's leading edge link to ECM via integrins. Actomyosin contraction then allows for the disassembly of adhesions in the rear and movement forward [31]. Thus, movement of the fibroblasts in the wound site is regulated not only by the ECM and adhesion molecules, but also by the actin cytoskeleton. Actin cytoskeleton is also involved in fibroblast contractile phenotype. During dermis healing, fibroblasts generate stress fibers (weakly contractile actin bundles) to enable contraction [22]. Fibroblasts' shape is regulated by the environment and cell-matrix adhesion determines the cell shape, such as strong cell-ECM adhesion promotes spindle-shaped fibroblast [32]. In vitro fibroblasts were shown to have different morphology depending on the substrate they

Table 2 Cytoskeleton genes regulated by FGF2 treatment

\begin{tabular}{lllll}
\hline Symbol & Name & Log2 fold change & Fold change & Adjusted $\mathbf{p}$-value \\
\hline TUBA4A & Tubulin, alpha 4a & 1.29 & 2.44 & 0.000256991 \\
TUBB3 & Tubulin, beta 3 class III & 1.14 & 2.20 & 0.00119515 \\
TUBA1C & Tubulin, alpha 1C & 0.95 & 1.93 & 0.002708545 \\
TUBB2C & Tubulin, beta 2C & 0.60 & 1.52 & 0.020192536 \\
ACTA2 & Actin, alpha 2, smooth muscle, aorta & -0.86 & -1.81 & 0.00445901 \\
ACTN1 & Actinin & -1.38 & -2.60 & $1.90 \mathrm{E}-05$ \\
TUBE1 & Tubulin, epsilon 1 & -1.42 & -2.68 & 0.000182139 \\
TUBG2 & Tubulin, gamma 2 & -2.71 & -6.53 & 0.000159057 \\
ACTC1 & Actin, alpha, cardiac muscle 1 & -4.38 & -20.83 & $4.46 \mathrm{E}-11$ \\
ACTG2 & Actin, gamma 2, smooth muscle, enteric & -6.01 & -64.33 & $1.52 \mathrm{E}-13$ \\
\hline
\end{tabular}




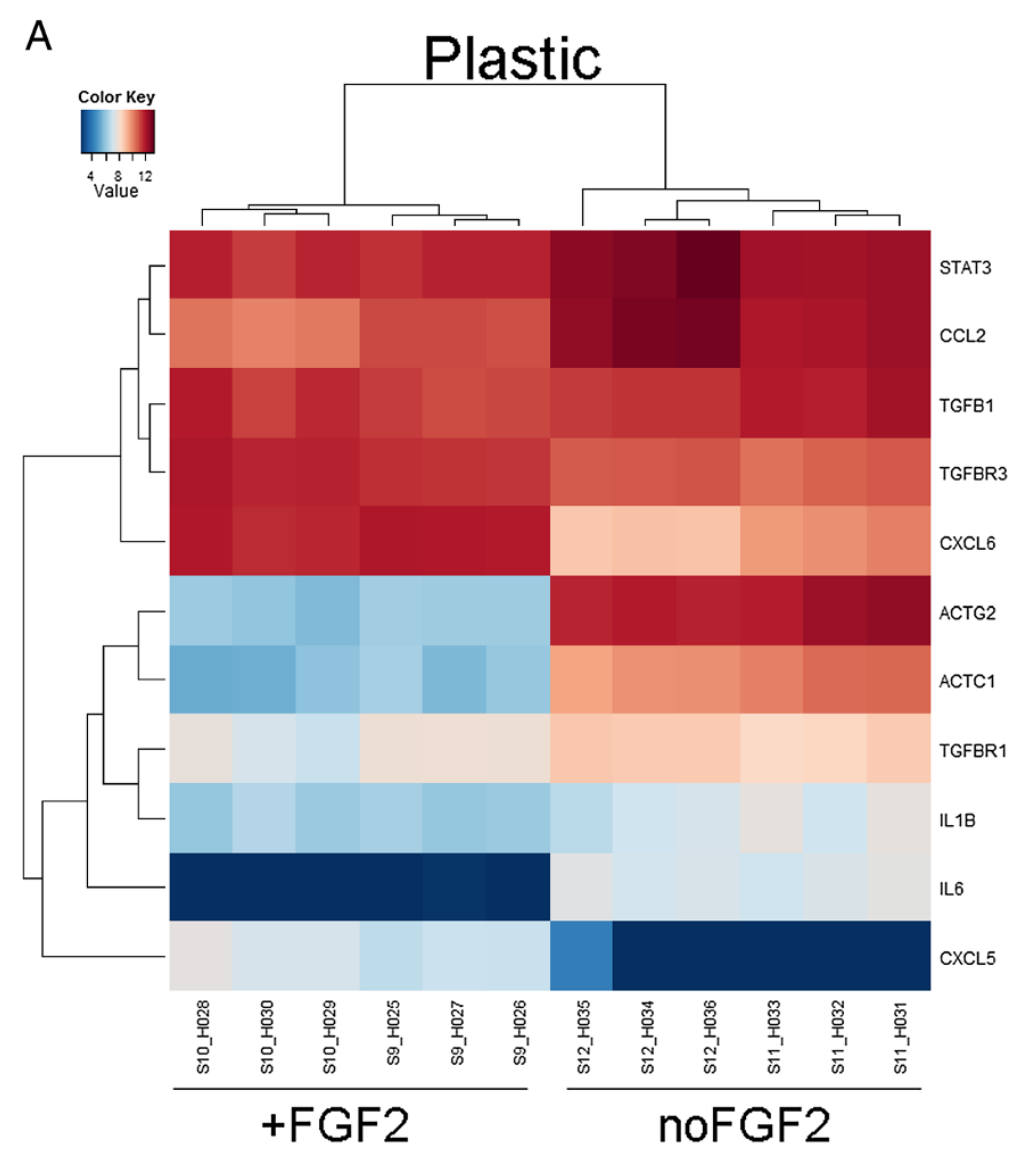

B

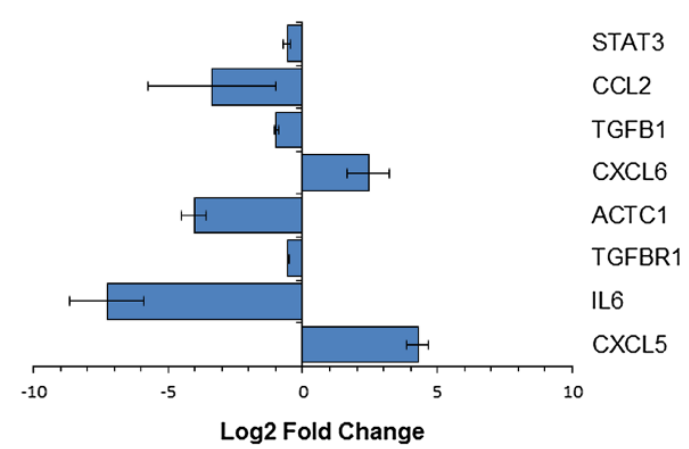

Figure 5 FGF2 affects expression levels of cytoskeleton genes and chemokines. A. Heat map showing expression levels of select genes as identified by microarray analysis. B. qRT-PCR validation of microarray data for select genes. Expression levels were normalized to ACTB and are represented as log2 Fold change (FGF2-treated compared to untreated). Error bars represent SEM. GRT-PCR for IL1B, ACTG2, and TGBR3 did not show change in the expression levels.

are grown on; in $3 \mathrm{D}$ cultures resembling an in vivo environment, fibroblasts display elongated shape, welldeveloped actin cortex, and filopodia at the leading edge [33]. Alpha actin ACTC1, which is a constituent of the contractile apparatus, was downregulated in human dermal fibroblasts treated with FGF2 (Table 2; Figure 5B). Gamma actin ACTG2, which is involved in cellular motility and adhesion, was 64-fold downregulated (Table 2), though qRT-PCR did not confirm its expression.
By regulating cytoskeleton gene expression, FGF2 potentially promotes cell migration in the wound site, and reduces contraction that leads to the favorable pro-regenerative outcome.

Previously, it was shown that administration of FGF2 alone into a dermal wound shows reduced scar formation [15], which can be attributed to upregulation of matrix metalloproteinase MMP1 [17]. Our data shows strong upregulation of MMP1 (Figure 4B), the metalloproteinase 
Table 3 Representative cytokines regulated by FGF2

\begin{tabular}{|c|c|c|c|c|}
\hline Symbol & Name & $\begin{array}{l}\text { Log2 } \\
\text { fold change }\end{array}$ & Fold change & $\begin{array}{l}\text { Adjusted } \\
\text { p-value }\end{array}$ \\
\hline \multicolumn{5}{|c|}{ Chemokines } \\
\hline CXCL5 & Chemokine (C-X-C motif) ligand 5 & 4.58 & 16.78 & $9.18 \mathrm{E}-07$ \\
\hline CXCL6 & Chemokine (C-X-C motif) ligand 6 (granulocyte chemotactic protein 2) & 2.50 & 5.64 & $1.23 \mathrm{E}-07$ \\
\hline CXCL1 & Chemokine (C-X-C motif) ligand 1 (melanoma growth stimulating activity, alpha) & 2.06 & 4.17 & $1.59 \mathrm{E}-05$ \\
\hline CCL22 & Chemokine (C-C motif) ligand 22 & 1.55 & 2.93 & 0.033547076 \\
\hline C5 & Complement component 5 & 0.88 & 1.85 & 0.001196477 \\
\hline CCL26 & Chemokine (C-C motif) ligand 26 & -0.67 & -1.59 & 0.027966918 \\
\hline CCL14 & Chemokine (C-C motif) ligand 14 & -1.15 & -2.22 & 0.000191918 \\
\hline CCL25 & Chemokine (C-C motif) ligand 25 & -1.23 & -2.35 & 0.007193543 \\
\hline CCL2 & Chemokine (C-C motif) ligand 2 & -1.79 & -3.46 & $6.20 \mathrm{E}-06$ \\
\hline \multicolumn{5}{|c|}{ Chemokine receptors } \\
\hline CCRL1 & Chemokine (C-C motif) receptor-like 1 & 2.02 & 4.06 & $1.37 \mathrm{E}-05$ \\
\hline CCR10 & Chemokine (C-C motif) receptor 10 & 0.98 & 1.97 & 0.043411565 \\
\hline CCR8 & Chemokine (C-C motif) receptor 8 & -0.58 & -1.49 & 0.047496414 \\
\hline CXCR7 & Chemokine (C-X-C motif) receptor 7 & -2.26 & -4.79 & $1.24 \mathrm{E}-06$ \\
\hline \multicolumn{5}{|c|}{ Interleukins } \\
\hline IL8 & Interleukin 8 & 1.47 & 2.77 & 0.013242716 \\
\hline IL17D & Interleukin 17D & 1.41 & 2.66 & 0.000124442 \\
\hline ILIRN & Interleukin 1 receptor antagonist & 1.18 & 2.27 & 0.007602993 \\
\hline IL1B & Interleukin 1, beta & -1.10 & -2.14 & 0.002340469 \\
\hline IL2 & Interleukin 2 & -1.19 & -2.28 & 0.034673096 \\
\hline IL32 & Interleukin 32 & -1.19 & -2.28 & 0.000974257 \\
\hline IL1RAP & Interleukin 1 receptor accessory protein & -1.91 & -3.76 & 8.85E-06 \\
\hline IL33 & Interleukin 33 & -2.59 & -6.02 & 0.000613327 \\
\hline IL6 & Interleukin 6 (interferon, beta 2) & -5.07 & -33.59 & $2.75 \mathrm{E}-07$ \\
\hline \multicolumn{5}{|c|}{ Interleukin receptors } \\
\hline IL17RD & Interleukin 17 receptor D & 2.24 & 4.72 & 0.00026435 \\
\hline IL13RA2 & Interleukin 13 receptor, alpha 2 & 1.84 & 3.58 & $3.65 \mathrm{E}-05$ \\
\hline IL15RA & Interleukin 15 receptor, alpha & 0.71 & 1.64 & 0.015033555 \\
\hline IL21R & Interleukin 21 receptor & -0.86 & -1.82 & 0.004974339 \\
\hline IL20RB & Interleukin 20 receptor beta & -1.29 & -2.45 & 0.000238276 \\
\hline IL1RL1 & Interleukin 1 receptor-like 1 & -1.99 & -3.97 & 0.002708422 \\
\hline \multicolumn{5}{|l|}{ STAT } \\
\hline STAT4 & Signal transducer and activator of transcription 4 & -1.51 & -2.85 & $1.15 \mathrm{E}-06$ \\
\hline STAT1 & Signal transducer and activator of transcription 1 & -0.87 & -1.83 & 0.006745 \\
\hline STAT3 & Signal transducer and activator of transcription 3 (acute-phase response factor) & -0.87 & -1.83 & 0.021783 \\
\hline \multicolumn{5}{|c|}{ Tumor necrosis factor family } \\
\hline TNFAIP8L1 & Tumor necrosis factor, alpha-induced protein 8-like 1 & 3.90 & 14.93 & $8.62 \mathrm{E}-07$ \\
\hline TNFRSF25 & Tumor necrosis factor receptor superfamily, member 25 & 1.89 & 3.71 & 0.000432746 \\
\hline TNFSF10 & Tumor necrosis factor (ligand) superfamily, member 10 & 1.74 & 3.34 & 0.005536998 \\
\hline TNFAIP8L3 & Tumor necrosis factor, alpha-induced protein 8-like 3 & 1.31 & 2.48 & $9.01 \mathrm{E}-05$ \\
\hline TNFRSF1B & Tumor necrosis factor receptor superfamily, member 1B & 1.20 & 2.30 & 0.027881915 \\
\hline TNFRSF21 & Tumor necrosis factor receptor superfamily, member 21 & 0.67 & 1.59 & 0.029823686 \\
\hline
\end{tabular}


Table 3 Representative cytokines regulated by FGF2 (Continued)

\begin{tabular}{|c|c|c|c|c|}
\hline C1QTNF6 & $\mathrm{Clq}$ and tumor necrosis factor related protein 6 & -0.70 & -1.62 & 0.035969462 \\
\hline TNFRSF10B & Tumor necrosis factor receptor superfamily, member $10 \mathrm{~b}$ & -0.75 & -1.68 & 0.025993715 \\
\hline C1QTNF3 & $\mathrm{Clq}$ and tumor necrosis factor related protein 3 & -0.81 & -1.75 & 0.013142151 \\
\hline TNFAIP6 & Tumor necrosis factor, alpha-induced protein 6 & -0.85 & -1.80 & 0.021930255 \\
\hline TNFAIP1 & Tumor necrosis factor, alpha-induced protein 1 (endothelial) & -0.87 & -1.83 & 0.002670969 \\
\hline TNFRSF10D & $\begin{array}{l}\text { Tumor necrosis factor receptor superfamily, member 10d, decoy with truncated death } \\
\text { domain }\end{array}$ & -1.14 & -2.20 & 0.003564267 \\
\hline TNFRSF11B & Tumor necrosis factor receptor superfamily, member $11 \mathrm{~b}$ & -1.59 & -3.01 & 4.04E-05 \\
\hline $\begin{array}{l}\text { C1QTNF5 } \\
\text { MFRP }\end{array}$ & $\begin{array}{l}\text { Membrane frizzled-related protein, } \mathrm{Clq} \text { and tumor necrosis factor related protein } 5 \\
\text { transcription unit }\end{array}$ & -2.42 & -5.35 & 5.17E-10 \\
\hline TNFSF4 & Tumor necrosis factor (ligand) superfamily, member 4 & -2.83 & -7.11 & 4.13E-09 \\
\hline \multicolumn{5}{|c|}{ TGFB pathway } \\
\hline TGFBR3 & Transforming growth factor, beta receptor 3 & 0.94 & 1.92 & 0.001259518 \\
\hline TGFBI & Transforming growth factor, beta-induced, 68kDa & -0.66 & -1.58 & 0.014441976 \\
\hline TGFBR1 & Transforming growth factor, beta receptor 1 & -0.96 & -1.91 & 0.005746781 \\
\hline
\end{tabular}

responsible for cleaving collagen type I, II, and III [34]. FGF2 signaling was shown to activate the MMP1 promoter [35]. MMP1 was able to improve the skeletal muscle regeneration process by reducing scar tissue formation [36-38] and by promoting migration of myoblasts involved in regeneration of skeletal muscle $[39,40]$. Interestingly, integrin $\alpha 2 \beta 1$ was shown to increase MMP1 expression $[41,42]$. By transplanting FGF2 treated human dermal fibroblasts, continuous increase in production of MMP1 among other factors, may be allowed, indicating that MMP1 is present not only at the time of the resolution phase of wound healing leading to decreased collagen production, but also at earlier stages of wound healing, for example during the inflammation stage. Other MMP molecules, such as stromelysins MMP3, MMP10, MMP11, were upregulated as well (Table 1 and Figure 4). MMP3 was previously shown to be responsible for contraction of fibroblasts during wound healing [43] and was regulated by FGF2 in a mouse model [44]. MMPs, mostly MMP2, 3, 9 and 10, are highly upregulated during amphibian limb regeneration [45-47]. All of these observations point toward a favorable role of MMPs in the regeneration process. Thus, FGF2-stimulated change in transcriptional profile of various MMPs is an important factor contributing to the regenerationcompetence of fibroblasts.

FGF2 treatment also led to a favorable ratio between MMPs and tissue inhibitors of metalloproteinases (TIMPs), as an imbalance between MMPs and TIMPs has been shown to increase scar formation. FGF2 upregulated TIMP4 and downregulated TIMP3 expression (Figure 4B). ADAM and ADAMTS proteinases that were shown to be differentially regulated by FGF2 (Table 1) are regulators of ECM and adhesion molecules and affect cell motility, adhesion, and signaling during wound healing processes. ADAMTS1 and ADAMTS5 were downregulated by FGF2 treatment (Figure 4B). ADAM transmembrane proteinases are involved in cleaving and activating various cell surface molecules, whereas ADAMTS are secreted proteinases that can bind ECM. ADMATS8 that was upregulated by FGF2 treatment (Figure 4B) has anti-angiogenic properties [48].

The ratio of TGFB1/TGFB3 is a factor that predicts scar formation, the decrease in this ratio being indicative of reduced scar formation [11]. Fetal wounds that are known to heal without scar formation exhibit decreased TGFB1 levels [49]. Administration of TGFB3 has also been shown to reduce scar formation [15]. TGFB pathway was previously shown to be induced by FGF2 treatment in mouse embryonic fibroblasts (MEFs) [50]. We observed no change in the levels of TGFB1 due to FGF2 treatment by microarray analysis whereas qRT-PCR showed downregulation of TGFB1 levels (Figure 5B). We observed upregulation of TGFBR3 due to FGF2 treatment by the array, but qRT-PCR showed no change in expression levels (Figure 5B). qRT-PCR confirmed downregulation of TGFBR1 (Figure $5 \mathrm{~B}$ ). These observations may be due to differences between mouse embryonic fibroblasts and adult human dermal fibroblasts, indicating that FGF2 response in these cells may be unique.

Decreasing inflammation has been shown to decrease scar formation. For example, when wounds of skin and oral mucosa were compared, there was less inflammation and scarring in oral mucosa [51]. Non-scar wound healing in fetal wounds is also characterized by absence of inflammation [52-56]. Inflammatory events are integrated by chemokines. Chemokines are chemotactic cytokines that regulate migration of cells during inflammatory process. 
$\operatorname{ELR}\left({ }^{+}\right)$CXC chemokines are neutrophil attractants and activators. CXCL6 or granulocyte chemotactic protein-2 (GCP-2) is a $\operatorname{ELR}\left(^{+}\right)$CXC chemokine. FGF2 treatment led to increase in CXCL6 chemokine expression (Figure 5B). CXCL5, a chemokine that attracts and activates neutrophils, amplifies inflammatory cascade, and stimulates local production of cytokines was shown to be upregulated by FGF2 treatment (Figure 5B). Interestingly, when CXCL5 is cleaved by MMP1, 2, 8, 9, and 13, increased inflammation is observed and cell recruitment to the wound site is activated [57]. CCL2 (monocyte chemoattractant protein-1, MCP-1), which is involved in inflammatory cell recruitment, can be induced through focal adhesion kinase (FAK) leading to inflammation and scar production in a cutaneous injury, and CCL2 knock-out mice showed decreased scarring [58]. Here, we observed downregulation of CCL2 due to FGF2 treatment (Figure 5B). In agreement with previous publications, implantation of FGF2 treated fibroblasts, which show CCL2 downregulation, into a mouse wound sight leads to reduced scar formation [19]. We also show in this transcriptome analysis that IL6/ STAT3 signaling pathway is regulated by FGF2 (Figure 5B). Interleukin 6 (IL6) is a pleiotropic cytokine that is produced by a variety of cells such as epidermal cells, endothelial cells, and fibroblasts [59]. IL6 is known to increase production of collagen [60], thus the decrease in collagen synthesis that we observe in skeletal muscle injury, can be partially explained by decrease in IL6. CCL2 was shown to induce IL6 secretion in human lung fibroblasts, and has a role in regulating fibrosis [61] and was shown previously to be regulated by FGF2 [62]. Scarless, fetal wounds are characterized by diminished expression of pro-inflammatory IL6 and IL8 [52,53]. Here, we show that FGF2 treatment significantly reduces IL6 levels (Figure 5B), whereas levels of IL8 are upregulated with FGF2 treatment (Table 3). FGF2-induced decrease in IL6 level could be contributing to pro-regenerative phenotype of adult human fibroblasts. Signal transducer and activator of transcription (STAT3) conveys signals from IL6. Loss of IL6 was shown to result in deficiency of proliferation and migration of myoblasts [63-65]. IL6/STAT3 was shown recently to be involved in excessive ECM production and increased cellular proliferation in hypertrophic scars compared to normal human fibroblasts [66].

\section{Conclusions}

Comparison of transcriptomes between control and regeneration-competent fibroblasts indicates significant differences in expression of genes involved in several biological processes during wound healing. Downregulation of collagens, upregulation of ECM remodeling enzymes, and downregulation of pro-inflammatory cytokines may be in part responsible for the cells' pro-regenerative phenotype. A choice between scar-forming and proregenerative wound healing responses may depend on a balance between ECM production, degradation, consequent ECM contractility, and decreased inflammatory response. Further studies are needed to elucidate functional significance of specific disregulated genes.

\section{Methods}

\section{Cell culture}

Adult human dermal fibroblasts were obtained from ATCC (CRL-2352) at passage number 1 (p1). Cells were expanded using culture conditions recommended by the supplier, namely ambient oxygen, $5 \% \mathrm{CO}_{2}$ in air, $37^{\circ} \mathrm{C}$ in DMEM/F12 and 10\% FBS. Expansion was done by trypsinizing $(0.05 \%$ trypsin, Cellgro) the cells at $80 \%$ confluence and replating them at a density of 14,000 cells $/ \mathrm{cm}^{2}$. Cells were cryopreserved with DMSO and the same passage used for all the experimental groups. Cells from the same passage number 7 were grown for seven days at $5 \% \mathrm{O}_{2}, 5 \% \mathrm{CO}_{2}, 37^{\circ} \mathrm{C}$ in DMEM/F12 and $10 \%$ FCIII in one of the following culture conditions: 1 . with $4 \mathrm{ng} / \mathrm{ml}$ human recombinant FGF2 (PeproTech) on tissue culture plastic; 2. with $4 \mathrm{ng} / \mathrm{ml}$ human recombinant FGF2 on glass culture surface; 3 . on tissue culture plastic; and 4. on glass culture surface. After 7 days, cells were used for three RNA collections for transcriptome arrays and qRT-PCR.

\section{RNA isolation}

Total RNA was isolated from all treatment groups using TRIZOL reagent (Invitrogen) following manufacturer's protocol.

\section{OneArray microarray sample and data processing}

To obtain a sense of global effects of surface and FGF2, two independent samples (in three technical replicates each) of cells grown on glass, glass with FGF2, plastic, and plastic with FGF2 were hybridized to the Human Whole Genome OneArray v5 (Phalanx Biotech, Palo Alto, CA). RNA quality and integrity were determined utilizing an Agilent 2100 Bioanalyzer (Agilent Technologies, Palo Alto, CA, USA) and absorbance at A260/A280. Only high quality RNA, having a RIN of $>7.0$, and an A260/280 absorbance ratio of $>1.8$, was utilized for further experimentation. RNA was converted to double-stranded cDNA and amplified using in vitro transcription that included amino-allyl UTP, and the aRNA product was subsequently conjugated with $\mathrm{Cy}^{\mathrm{mm}} \mathrm{NHS}$ ester $(\mathrm{GEH}$ Lifesciences). Fragmented aRNA was hybridized at $50^{\circ} \mathrm{C}$ overnight using the HybBag mixing system with $1 \mathrm{X}$ OneArray Hybridization Buffer (Phalanx Biotech), $0.01 \mathrm{mg} / \mathrm{ml}$ sheared salmon sperm DNA (Promega, Madison, WI, USA), at a concentration of $0.025 \mathrm{mg} / \mathrm{ml}$ labeled target. After hybridization, the arrays were washed according to the OneArray protocol. Raw intensity signals 
for each microarray were captured using a Molecular Dynamics $^{\text {Thx }}$ Axon 4100A scanner, measured using GenePixPro $^{\text {tw }}$ Software, and stored in GPR format.

\section{Data analysis}

The data was analyzed with $\mathrm{R} /$ bioconductor using standard statistical functions and analysis modules for the ANOVA, T test, FDR, and functional analysis $[67,68]$. Analysis was performed in the following order. First, data was background corrected, normalized, and filtered to remove probes with very low expression or low variance (expression but no variation) across conditions. Next, 2-way ANOVA was performed to determine significant gene probes for the two factors and possible interactions between cell culture surface and FGF2. LIMMA package was used to determine significantly differentially expressed genes (DEG) with moderate t-statistic as main statistic of significance and standard errors moderated using Bayesian model [69-71]. P-values were adjusted for multiple comparisons using Benjamini and Hochberg method to control the false discovery rate (FDR) [72]. FDR cutoff value of 0.05 was used.

Gene Ontology (GO) analysis was performed to analyze functional enrichment within DEG due to FGF2 treatment in human dermal fibroblasts cultured on plastic. DEG due to FGF2 treatment were profiled for GO slim using geneListPie package [73]. In order to perform GO analysis, GOstats package was used [74]. Hypergeometric conditional testing was performed to obtain overrepresented GO terms that belong to three groups: biological process, molecular function, and cellular component.

\section{Quantitative RT-PCR}

cDNA was prepared from total RNA using QuantiTect Reverse Transcription kit (Qiagen) using mixture of oligo-dT and random primers method. The kit also includes elimination of genomic DNA step prior to reverse transcription. $1 \mu \mathrm{g}$ of total RNA was used for cDNA preparation. For each qPCR reaction $20 \mathrm{ng}$ of cDNA were used. qPCR was performed using SYBR SELECT master mix (Invitrogen). The list of primers can be found in Additional file 7. Quantification of qPCR results was performed by the $\Delta \Delta C T$ method.

\section{Availability of supporting data}

The data sets supporting the results of this article are available in Gene Expression Omnibus (GEO) repository (GSE48967) and at http://users.wpi.edu/ tdominko/iRC_transcriptome/.

\section{Additional files}

Additional file 1: 11,124 filtered probes. Matrix of background corrected, normalized, and filtered log2 intensity values.
Additional file 2: Pearson's correlation coefficients. Scatter plots and correlation coefficients comparing two biological replicates for each of four experimental groups: A. adult human dermal fibroblasts cultured on glass with addition of $4 \mathrm{ng} / \mathrm{ml} \mathrm{FGF2,} \mathrm{B.} \mathrm{adult} \mathrm{human} \mathrm{dermal} \mathrm{fibroblasts}$ cultured on glass, $\mathrm{C}$. adult human dermal fibroblasts cultured on plastic

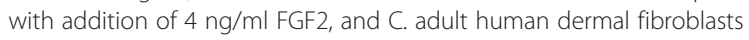
cultured on plastic.

Additional file 3: Glass FvsU. List of significantly differentially expressed genes due to FGF2 treatment of adult human dermal fibroblasts cultured on glass.

Additional file 4: Plastic FvsU. List of significantly differentially expressed genes due to FGF2 treatment of adult human dermal fibroblasts cultured on tissue culture plastic.

Additional file 5: GOslim. GO slim terms associated with biological process, molecular function, and cellular component of genes affected by FGF2 treatment of adult human dermal fibroblasts grown on tissue culture plastic.

Additional file 6: GOterms. Results of functional annotation using Gene Ontology. GO terms belong to three groups: biological process, molecular function, and cellular component.

Additional file 7: Primers. List of primers used for qRT-PCR analysis.

\section{Competing interests}

The authors declare that they have no competing interests.

\section{Authors' contributions}

All authors read and approved the final manuscript. OK and TD drafted manuscript. DLP, EFR, SA and OK performed the bioinformatics analysis. SA and OK harvested the cells. OK performed qRT-PCR analysis.

\section{Acknowledgements}

This work was supported by the grant from the NIH (\#R01GM85456) to Tanja Dominko.

\section{Author details}

'Department of Biology and Biotechnology, Worcester Polytechnic Institute, 100 Institute Road, Worcester, MA 01609, USA. ${ }^{2}$ Department of Cell and Developmental Biology, University of Massachusetts Medical School, 55 Lake Avenue North, Worcester, MA 01655, USA. ${ }^{3}$ Department of Biomedical Engineering, Worcester Polytechnic Institute, 100 Institute Road, Worcester, MA 01609, USA.

Received: 20 March 2013 Accepted: 24 September 2013

Published: 26 September 2013

\section{References}

1. Whitfield ML, Sherlock G, Saldanha AJ, Murray Jl, Ball CA, Alexander KE, Matese JC, Perou CM, Hurt MM, Brown PO, et al: Identification of genes periodically expressed in the human cell cycle and their expression in tumors. Mol Biol Cell 2002, 13(6):1977-2000.

2. Cooper S, Shedden K: Microarray analysis of gene expression during the cell cycle. Cell Chromosome 2003, 2(1):1.

3. Cho RJ, Huang M, Campbell MJ, Dong H, Steinmetz L, Sapinoso L, Hampton G, Elledge SJ, Davis RW, Lockhart DJ: Transcriptional regulation and function during the human cell cycle. Nat Gene 2001, 27(1):48-54.

4. Forsyth NR, Kay A, Hampson K, Downing A, Talbot R, McWhir J: Transcriptome alterations due to physiological normoxic $(2 \%$ O2) culture of human embryonic stem cells. Regen Med 2008, 3(6):817-833.

5. Shahdadfar A, Fronsdal K, Haug T, Reinholt FP, Brinchmann JE: In vitro expansion of human mesenchymal stem cells: choice of serum is a determinant of cell proliferation, differentiation, gene expression, and transcriptome stability. Stem Cells 2005, 23(9):1357-1366.

6. Derda R, Li L, Orner BP, Lewis RL, Thomson JA, Kiessling LL: Defined substrates for human embryonic stem cell growth identified from surface arrays. ACS Chem Biol 2007, 2(5):347-355.

7. Rodin S, Domogatskaya A, Strom S, Hansson EM, Chien KR, Inzunza J, Hovatta O, Tryggvason K: Long-term self-renewal of human pluripotent stem cells on human recombinant laminin-511. Nat Biotechnol 2010, 28(6):611-615. 
8. Xu C, Inokuma MS, Denham J, Golds K, Kundu P, Gold JD, Carpenter MK Feeder-free growth of undifferentiated human embryonic stem cells. Nat Biotechnol 2001, 19(10):971-974

9. Ludwig TE, Bergendahl V, Levenstein ME, Yu J, Probasco MD, Thomson JA: Feeder-independent culture of human embryonic stem cells. Nat Methods 2006, 3(8):637-646.

10. Braam SR, Zeinstra L, Litjens S, Ward-van Oostwaard D, van den Brink S, van Laake L, Lebrin F, Kats P, Hochstenbach R, Passier R, et al: Recombinant vitronectin is a functionally defined substrate that supports human embryonic stem cell self-renewal via alphavbeta5 integrin. Stem Cells 2008, 26(9):2257-2265

11. Chen G, Gulbranson DR, Hou Z, Bolin JM, Ruotti V, Probasco MD, SmugaOtto K, Howden SE, Diol NR, Propson NE, et al: Chemically defined conditions for human iPSC derivation and culture. Nat Method 2011 8(5):424-429.

12. Rowland TJ, Miller LM, Blaschke AJ, Doss EL, Bonham AJ, Hikita ST, Johnson LV, Clegg DO: Roles of integrins in human induced pluripotent stem cell growth on Matrigel and vitronectin. Stem Cells Dev 2010, 19(8):1231-1240

13. Chen W, Villa-Diaz LG, Sun Y, Weng S, Kim JK, Lam RH, Han L, Fan R, Krebsbach $\mathrm{PH}, \mathrm{Fu} \mathrm{J}$ : Nanotopography influences adhesion, spreading, and self-renewal of human embryonic stem cells. ACS Nano 2012, 6(5):4094-4103.

14. Sun Y, Villa-Diaz LG, Lam RH, Chen W, Krebsbach PH, Fu J: Mechanics regulates fate decisions of human embryonic stem cells. PLoS One 2012, 7(5):e37178.

15. Ono I, Akasaka Y, Kikuchi R, Sakemoto A, Kamiya T, Yamashita T, Jimbow K: Basic fibroblast growth factor reduces scar formation in acute incisional wounds. Wound Repair Regen 2007, 15(5):617-623.

16. Eto H, Suga H, Aoi N, Kato H, Doi K, Kuno S, Tabata Y, Yoshimura K: Therapeutic potential of fibroblast growth factor- 2 for hypertrophic scars: upregulation of MMP-1 and HGF expression. Lab Invest 2012, 92(2):214-223.

17. Xie J, Bian H, Qi S, Xu Y, Tang J, Li T, Liu X: Effects of basic fibroblast growth factor on the expression of extracellular matrix and matrix metalloproteinase1 in wound healing. Clin Exp Dermatol 2008, 33(2):176-182.

18. Page RL, Ambady S, Holmes WF, Vilner L, Kole D, Kashpur O, Huntress V, Vojtic I, Whitton H, Dominko T: Induction of stem cell gene expression in adult human fibroblasts without transgenes. Cloning Stem Cells 2009, 11(3):417-426

19. Page RL, Malcuit C, Vilner L, Vojtic I, Shaw S, Hedblom E, Hu J, Pins GD, Rolle MW, Dominko T: Restoration of skeletal muscle defects with adult human cells delivered on fibrin microthreads. Tissue Eng Part A 2011, 17(21-22):2629-2640.

20. Gurtner GC, Werner S, Barrandon Y, Longaker MT: Wound repair and regeneration. Nature 2008, 453(7193):314-321.

21. Sorrell JM, Caplan Al: Fibroblast heterogeneity: more than skin deep. J Cell Sci 2004, 117(Pt 5):667-675

22. Shaw TJ, Martin P: Wound repair at a glance. J Cell Sci 2009, 122(Pt 18):3209-3213.

23. Li W, Fan J, Chen M, Guan S, Sawcer D, Bokoch GM, Woodley DT: Mechanism of human dermal fibroblast migration driven by type I collagen and platelet-derived growth factor-BB. Mol Biol Cell 2004, 15(1):294-309.

24. Martin P: Wound healing-aiming for perfect skin regeneration. Science 1997, 276(5309):75-81.

25. Eckes B, Nischt R, Krieg T: Cell-matrix interactions in dermal repair and scarring. Fibrogenesis tissue repair 2010, 3:4

26. Sottile J, Hocking DC: Fibronectin polymerization regulates the composition and stability of extracellular matrix fibrils and cell-matrix adhesions. Mol Biol Cell 2002, 13(10):3546-3559.

27. Velling T, Risteli J, Wennerberg K, Mosher DF, Johansson S: Polymerization of type I and III collagens is dependent on fibronectin and enhanced by integrins alpha 11 beta 1 and alpha 2beta 1. J Biol Chem 2002, 277(40):37377-37381.

28. Wierzbicka-Patynowski I, Schwarzbauer JE: The ins and outs of fibronectin matrix assembly. J cell sci 2003, 116(Pt 16):3269-3276.

29. Rossier O, Octeau V, Sibarita JB, Leduc C, Tessier B, Nair D, Gatterdam V, Destaing O, Albiges-Rizo C, Tampe R, et al: Integrins beta1 and beta3 exhibit distinct dynamic nanoscale organizations inside focal adhesions. Nat Cell Biol 2012, 14(10):1057-1067.

30. Huttenlocher A, Horwitz AR: Integrins in cell migration. Cold Spring Harb Perspect Biol 2011, 3(9):a005074.

31. Parsons JT, Horwitz AR, Schwartz MA: Cell adhesion: integrating cytoskeletal dynamics and cellular tension. Nat Rev Mol Cell Biol 2010, 11(9):633-643

32. Friedl $P$, Wolf $K$ : Plasticity of cell migration: a multiscale tuning model. J Cell Biol 2010, 188(1):11-19.
33. Walpita D, Hay E: Studying actin-dependent processes in tissue culture. $N$ Rev Mol Cell Biol 2002, 3(2):137-141.

34. Page-McCaw A, Ewald AJ, Werb Z: Matrix metalloproteinases and the regulation of tissue remodelling. Nat Rev Mol Cell Biol 2007, 8(3):221-233.

35. Newberry EP, Willis D, Latifi T, Boudreaux JM, Towler DA: Fibroblast growth factor receptor signaling activates the human interstitial collagenase promoter via the bipartite Ets-AP1 element. Mol Endocrinol 1997, 11(8):1129-1144.

36. Kaar JL, Li Y, Blair HC, Asche G, Koepsel RR, Huard J, Russell AJ: Matrix metalloproteinase-1 treatment of muscle fibrosis. Acta Biomaterialia 2008 , 4(5):1411-1420.

37. Bedair H, Liu TT, Kaar JL, Badlani S, Russell AJ, Li Y, Huard J: Matrix metalloproteinase-1 therapy improves muscle healing. J App/ Physiol 2007, 102(6):2338-2345.

38. Bellayr I, Holden K, Mu X, Pan H, Li Y: Matrix metalloproteinase inhibition negatively affects muscle stem cell behavior. Int J Clin Exp Pathol 2013, 6(2):124-141.

39. Wang W, Pan H, Murray K, Jefferson BS, Li Y: Matrix metalloproteinase-1 promotes muscle cell migration and differentiation. Am J Pathol 2009, 174(2):541-549.

40. Allen $\mathrm{DL}$, Teitelbaum DH, Kurachi K: Growth factor stimulation of matrix metalloproteinase expression and myoblast migration and invasion in vitro. Am J Physiol Cell Physiol 2003, 284(4):C805-815.

41. Riikonen T, Westermarck J, Koivisto L, Broberg A, Kahari VM, Heino J: Integrin alpha 2 beta 1 is a positive regulator of collagenase (MMP-1) and collagen alpha 1(I) gene expression. J Biol Chem 1995, 270(22):13548-13552.

42. Vihinen $\mathrm{P}$, Riikonen $\mathrm{T}$, Laine $\mathrm{A}$, Heino J: Integrin alpha 2 beta 1 in tumorigenic human osteosarcoma cell lines regulates cell adhesion, migration, and invasion by interaction with type I collagen. Cell Growth Differ 1996, 7(4):439-447.

43. Bullard KM, Mudgett J, Scheuenstuhl H, Hunt TK, Banda MJ: Stromelysin-1deficient fibroblasts display impaired contraction in vitro. J Surg Res 1999, 84(1):31-34.

44. Pintucci G, Yu PJ, Sharony R, Baumann FG, Saponara F, Frasca A, Galloway AC, Moscatelli D, Mignatti P: Induction of stromelysin-1 (MMP-3) by fibroblast growth factor-2 (FGF-2) in FGF-2-/- microvascular endothelial cells requires prolonged activation of extracellular signal-regulated kinases-1 and -2 (ERK-1/2). J Cell Biochem 2003, 90(5):1015-1025.

45. Vinarsky $V$, Atkinson DL, Stevenson TJ, Keating MT, Odelberg SJ: Normal newt limb regeneration requires matrix metalloproteinase function. Dev Biol 2005, 279(1):86-98.

46. Stevenson TJ, Vinarsky V, Atkinson DL, Keating MT, Odelberg SJ: Tissue inhibitor of metalloproteinase 1 regulates matrix metalloproteinase activity during newt limb regeneration. Dev Dyn 2006, 235(3):606-616.

47. Santosh N, Windsor LJ, Mahmoudi BS, Li B, Zhang W, Chernoff EA, Rao N, Stocum DL, Song F: Matrix metalloproteinase expression during blastema formation in regeneration-competent versus regeneration-deficient amphibian limbs. Dev Dyn 2011, 240(5):1127-1141.

48. Porter S, Clark IM, Kevorkian L, Edwards DR: The ADAMTS metalloproteinases. Biochem J 2005, 386(Pt 1):15-27.

49. Lin RY, Sullivan KM, Argenta PA, Meuli M, Lorenz HP, Adzick NS: Exogenous transforming growth factor-beta amplifies its own expression and induces scar formation in a model of human fetal skin repair. Annals surg 1995, 222(2):146-154

50. Greber B, Lehrach $\mathrm{H}$, Adjaye J: Fibroblast growth factor 2 modulates transforming growth factor beta signaling in mouse embryonic fibroblasts and human ESCS (hESCs) to support hESC self-renewal. Stem Cells 2007, 25(2):455-464.

51. Chen L, Arbieva ZH, Guo S, Marucha PT, Mustoe TA, DiPietro LA: Positional differences in the wound transcriptome of skin and oral mucosa. BMC Genom 2010, 11:471.

52. Liechty KW, Adzick NS, Crombleholme TM: Diminished interleukin 6 (IL-6) production during scarless human fetal wound repair. Cytokine 2000, 12(6):671-676.

53. Liechty KW, Crombleholme TM, Cass DL, Martin B, Adzick NS: Diminished interleukin-8 (IL-8) production in the fetal wound healing response. J Surg Res 1998, 77(1):80-84.

54. Martin P, D'Souza D, Martin J, Grose R, Cooper L, Maki R, McKercher SR: Wound healing in the PU.1 null mouse-tissue repair is not dependent on inflammatory cells. Curr Biol CB 2003, 13(13):1122-1128. 
55. Wulff BC, Parent AE, Meleski MA, DiPietro LA, Schrementi ME, Wilgus TA: Mast cells contribute to scar formation during fetal wound healing. J Invest Dermatol 2012, 132(2):458-465.

56. Lorenz HP, Longaker MT, Perkocha LA, Jennings RW, Harrison MR, Adzick NS: Scarless wound repair: a human fetal skin model. Development 1992, 114(1):253-259.

57. Gill SE, Parks WC: Metalloproteinases and their inhibitors: regulators of wound healing. Int J Biochem Cell Biol 2008, 40(6-7):1334-1347.

58. Wong WW, Rustad KC, Akaishi S, Sorkin M, Glotzbach JP, Januszyk M, Nelson ER, Levi K, Paterno J, Vial IN, et al: Focal adhesion kinase links mechanical force to skin fibrosis via inflammatory signaling. Nat Med 2012, 18(1):148-152.

59. Roy S, Khanna S, Rink C, Biswas S, Sen CK: Characterization of the acute temporal changes in excisional murine cutaneous wound inflammation by screening of the wound-edge transcriptome. Physiol Genomics 2008, 34(2):162-184

60. Duncan MR, Berman B: Stimulation of collagen and glycosaminoglycan production in cultured human adult dermal fibroblasts by recombinant human interleukin 6. J Invest Dermatol 1991, 97(4):686-692.

61. Liu X, Das AM, Seideman J, Griswold D, Afuh CN, Kobayashi T, Abe S, Fang Q, Hashimoto $M$, Kim H, et al: The CC chemokine ligand 2 (CCL2) mediates fibroblast survival through IL-6. Am J Respir Cell Mol Biol 2007, 37(1):121-128.

62. Delrieu I, Arnaud E, Ferjoux G, Bayard F, Faye JC: Overexpression of the FGF-2 24-kDa isoform up-regulates IL-6 transcription in NIH-3T3 cells. FEBS letters 1998, 436(1):17-22.

63. Serrano AL, Baeza-Raja B, Perdiguero E, Jardi M, Munoz-Canoves P: Interleukin- 6 is an essential regulator of satellite cell-mediated skeletal muscle hypertrophy. Cell Metab 2008, 7(1):33-44.

64. McKay BR, De Lisio M, Johnston AP, O'Reilly CE, Phillips SM, Tarnopolsky MA, Parise G: Association of interleukin-6 signalling with the muscle stem cell response following muscle-lengthening contractions in humans. PLOS one 2009, 4(6):e6027.

65. Toth KG, McKay BR, De Lisio M, Little JP, Tarnopolsky MA, Parise G: IL-6 induced STAT3 signalling is associated with the proliferation of human muscle satellite cells following acute muscle damage. PLoS one 2011, 6(3):e17392.

66. Ray S, Ju X, Sun H, Finnerty CC, Herndon DN, Brasier AR: The IL-6 TransSignaling-STAT3 Pathway Mediates ECM and Cellular Proliferation in Fibroblasts from Hypertrophic Scar. J Invest Dermatol 2013, 135(5):1212-1220.

67. R Core Team: R: A language and environment for statistical computing. Vienna, Austria: R Foundation for Statistical Computing; 2012.

68. Gentleman RC, Carey VJ, Bates DM, Bolstad B, Dettling M, Dudoit S, Ellis B, Gautier L, Ge Y, Gentry J, et al: Bioconductor: open software development for computational biology and bioinformatics. Genome Biol 2004, 5(10):R80

69. Smyth G: Limma: linear models for microarray data. In Bioinformatics and Computational Biology Solutions using $R$ and Bioconductor. Edited by Gentleman VC R, Dudoit S, Irizarry R, Huber W. New York: Springer; 2005:397-420

70. Gordon K, Smyth MR, Natalie T, James W, Wei S: limma: Linear Models for Microarray Data User's Guide (Now Including RNA-Seq Data Analysis). Firstth edition. Melbourne, Australia Bioinformatics Division: The Walter and Eliza Hall Institute of Medical Research; 2012.

71. Smyth GK: Linear models and empirical Bayes methods for assessing differential expression in microarray experiments. Stat App/ Genet Mol Biol 2004, 3:1

72. Benjamini YHY: Controlling the false discovery rate - a practical and powerful approach to multiple testing. J Roy Stat Soc B Met 1995, 57(1):289-300.

73. Deng X: geneListPie: Profiling a gene list into GOslim or KEGG function pie. R package version 1.0. ; 2012.

74. Gentleman SFaR: Using GOstats to test gene lists for GO term association. Bioinformatics 2007, 23(2):257-258.

doi:10.1186/1471-2164-14-656

Cite this article as: Kashpur et al.: FGF2-induced effects on

transcriptome associated with regeneration competence in adult

human fibroblasts. BMC Genomics 2013 14:656.

\section{Submit your next manuscript to BioMed Central and take full advantage of:}

- Convenient online submission

- Thorough peer review

- No space constraints or color figure charges

- Immediate publication on acceptance

- Inclusion in PubMed, CAS, Scopus and Google Scholar

- Research which is freely available for redistribution

Submit your manuscript at www.biomedcentral.com/submit 